\title{
Criminological Review of Criminal Action Involvement of Narcotics by Minors
}

\author{
Sem Jonathan Rakinaung ${ }^{1}$, Agus Salim ${ }^{2}$ \\ Dept.of Law, Universitas Kristen Indonesia Paulus, Indonesia ${ }^{1,2}$ \\ \{semrakinaung@gmail.com ${ }^{1}$ \}
}

\begin{abstract}
Makassar City, even though the officers are trying to prevent drugs, is very sad on the contrary that many minors are involved in drugs. In 2019, 16 minors were involved in drugs, in 2018 there were 13 children. The object of research is to examine the factors behind the criminal acts involving narcotics by minors in the city of Makassar; and reviewing efforts to tackle criminal acts involving narcotics by minors in the city of Makassar. The results showed, the factors that led to the crime of trafficking narcotics committed by children, namely, environmental factors around them, including:1) Family Factor. A household that does not have harmony in the household makes the child frustrated. Lack of attention and affection that is needed by the child makes the child disappointed and nervous. As an outlet for frustration with their disappointment, the child takes drugs to relieve the hurt he feels; 2) Environmental factor. Intercourse with children outside the home without the supervision of parents or family, children easily get bad associations. The life attitude of children who are still unstable will easily be affected by the involvement of narcotics trafficking, both being intermediaries and over time they will become consumptive; 3) Economic limitations. The vision to fulfill the economic limitations of children is that the sale of narcotics which is very promising to generate large amounts of money will lead to children trafficking narcotics as an intermediary for the sale and purchase of narcotics. Efforts that have been made in the prevention of the criminal act of trafficking narcotics committed by children, namely, pre-emptive efforts made in the form of eductive activities with the aim of knowing the causes, driving and opportunity factors of crime; Repressive measures are carried out by law enforcement officials after the occurrence of a criminal act. The purpose of the actions imposed on the perpetrators of drug trafficking crimes as a deterrent effect for the criminals of narcotics trafficking.
\end{abstract}

Keywords: Criminological Review of Criminal Action; Involvement of Narcotics; Minors

\section{Introduction}

The rise of narcotics cases is not only in the scope of adults but has spread to minors and has spread throughout the world. Many have died in vain due to overdose. Laws and weak 
officials have made the dangers of drugs more spread. This is very important for the government to overcome and prevent the circulation of narcotics cases that can damage the generation of the Indonesian country [1].

It is no longer a secret that the interaction of children in narcotics manipulated by traffickers to become narcotics couriers is a series of illicit conspiracies in carrying out the sale and purchase of narcotics illegally, while the capacity of children who are couriers is very worrying because it is clear that the child will comply with the law because he has committed a narcotics crime. Not only couriers, we found that minors are still innocent and easy by the persuasion of dealers and users of narcotics/drugs where at first the minors are given drugs for free then after they got addicted, the minors will never stop buy the drugs because of addicted by it.

The number of the drug abusers by children is really concerning that they have to consider the law because they have committed a crime and must be held accountable for the actions they have committed. A child who becomes a drug crime will be under the same laws and regulations as an adult perpetrator, only for child offenders, the trial process is different from that of adult offenders. Special protection provided to children by the state is regulated in Republic of Indonesia Law number 35 of 2014 concerning Amendments to Law Number 23 of 2002 concerning Child Protection, which in article 67 special protection for children who are victims of narcotics, alcohol, psychotropic substances, substances other addicts and children involved in their production and distribution are carried out through supervision, prevention and rehabilitation efforts [2]-[4].

The legal expert's view of the definition of children: 1) Augustine argues that children are not the same as adults, children who have a tendency to deviate from law and order because of limited knowledge and understanding of the realities of life, children are easier to learn with examples of what they receive from coercive rules; 2) John Locke gives the understanding that: "Children are individuals who are still clean and sensitive to stimuli from the environment,[5]

Throughout 2019 started from January to December, evidence of methamphetamine and marijuana drugs confiscated by the Makassar Police has increased compared to 2018. The Head of Makassar Police Narcotics Agency, Kompol Diary Astetika said that her party had confiscated 14.6 kilograms of crystal methamphetamine and $6.2 \mathrm{~kg}$ of marijuana from all areas in Makassar City. In 2019 the suspects were still dominated by male as many as 578 people, while female suspects were 77 people. There are 6 students, 8 students, 214 unemployed. This year there are 4 people working as Civil Service Staff. Most users are aged 31 years above [6].

Makassar City, even though the police continuously strive to prevent drugs, it is sad that found many underage children are involved in drugs. In 2019 there were 16 underage children involved in drugs while in 2018 there were 13 children. The limited ability of children needs and is important for law enforcement officers to see and focus to the application of punishment. The Number of law 11 of 2012 concerning the Juvenile Criminal Justice System as a substitute for Law Number 3 of 1997 concerning Juvenile Court will provide the application of punishment that is fostering and protecting children as perpetrators of criminal acts. Therefore, the protection of children is important, considering that children are the nation's next generation.

\section{Problem Formulation}

Based by the Introduction, the authors formulate the following research problems: 
a. What are the factors that cause the crime of trafficking narcotics committed by children in the city of Makassar?

b. How are the efforts to combat the criminal act of trafficking narcotics committed by children in the city of Makassar?

\section{Methodology}

The type of research used is Normative-Empirical to see social reality norms with realities in the field. Location of the research implementation in Makassar City, South Sulawesi Province, The approach method is a Normative approach (Legal Research), namely the statute approach, (Statue approach), the conceptual approach or using the empirical method (juridical sociological) and also can be combined the two approaches. As for the population and sample in this study were minors as victims of narcotics abusers. While the research sample consisted of 6 victims and traffickers.

Data analysis is describing and solving measurable problems based on variables, then discussing the subject matter which is normative. The analysis technique used is qualitative. What is meant by qualitative analysis is analysis by describing data in a quality manner in the form of regular, sequential, logical, non-overlapping and effective sentences so as to facilitate the understanding and interpretation of the data [7].

\section{Results and Discussions}

When we look closely, children are the most vulnerable family members, because of that children often become victims of negative behavior obtained from their families and the environment. The family and the surrounding environment have great potential to play an active role in protecting children in all matters that are intended to deviate. Children are often exposed to negative situations which should not be seen by children and who pay attention to the family and the surrounding environment who do not care about these things, whereas our future lies in whatever our utmost attention to our children. Children who are in adolescence are experiencing mental turmoil, so the deviant actions taken by children are a form of manifestation of the juvenile delinquency. Perverted actions they do without the intention of harming others. The deviant behavior of children cannot look absolutely the same as the deviant behavior committed by adults. Although in principle the actions are the same, the level of physical and emotional maturity of the child is still unstable, and the child's future should be taken into account in terms of proper treatment of them.

\section{Factors Causing the Crime of Narcotics Circulation Committed by Children}

The circulation of narcotics has become something of great concern because its circulation has spread everywhere regardless, both the top to the bottom, children, old, and young even do not know any profession, it has entered into a circle of narcotics trafficking. This is very unsettling for the community because it is a very dangerous threat not only to society but also a very serious threat to a country because it has the potential to destroy the state structure besides it can also damage the nation's generation.

In reality, whether it is felt or not, it is very clear that many problems arising from the circulation of narcotics are not in accordance with the rules and procedures established by the 
government, both through laws and regulations and government regulations, even many children are involved in cases. This is the data according the author got From Makassar Police. There are two factors that can lead to a crime. The first is the intentions of the perpetrators and the second is because of the opportunities they are in. Intention is a factor that comes from within the perpetrator.

Meanwhile, opportunity is a factor that comes from within the victim. This is because there is an action or behavior of the victim which encourages the perpetrator, who initially did not have the intention to commit the crime. From the results of the interviews, the data shows that the main factor that causes children to be involved in narcotics crimes in the city of Makassar is the environmental factor around them, both from the family environment and the social environment (association) and economic factors:

a. Household Factors. Likewise, a poor household can have a bad psychological effect on the mental development of the child, one of which is the absence of harmony in the household both with parents and siblings. Children who should get love and attention from those closest to them. If these desires and longings are not fulfilled and at all are contrary to the wishes of the child, this problem is one of the causes so that children vent their disappointments by frequently displaying deviant behavior that can disturb the family and even the community. Lack of attention and affection in this matter which is needed by the child makes the child feel frustrated and disappointed and anxious. As an outlet for frustration over their disappointment, children will find peace by consuming narcotics, and to meet the funding needs to buy these drugs / illegal substances, in the end it will lead to the involvement of narcotics crimes as couriers.

b. Environmental factor. Intercourse supports and greatly affects children, who are easily involved in narcotics crimes. The association of children outside the home without parental or family supervision, the child is easily affected within the scope of children who are accustomed to doing deviant things, including in the involvement of narcotics crimes, in this case it begins with a narcotics dealer and will certainly lead to the drug user.

c. Economic factors. Economic factors are also one of the crucial factors that greatly affect children. The dream of fulfilling the economic limitations of children, then the sale of narcotics which is very promising to make a lot of money will lead children to trafficking narcotics as an intermediary for the sale and purchase of narcotics, and there is a very good chance of becoming a drug user.

d. Prevention. The efforts made in overcoming the criminal act of trafficking narcotics by children are divided into three, namely pre-emptive efforts, preventive efforts, and repressive efforts. Pre-emptive efforts are made in the form of educational activities with the aim of knowing the factors causing, driving and opportunity factors of crime. Preventive measures are preventive efforts carried out in a systematic, planned, integrated and directed manner with the aim of trafficking narcotics by children. In an effort to prevent this, measures are also taken to narrow the space for children who are trafficking narcotics. Repressive measures are those undertaken by law enforcement officials after the occurrence of a criminal act. The purpose of the actions imposed on the perpetrators of drug trafficking crimes is a deterrent effect for the perpetrators of drug trafficking crimes.

\section{Conclusion}

The factors that cause the crime of narcotics by the minors: A broken harmony in the house can be affected to bad psychological for the mental development of the child. Children 
who should get love and attention from those closest to them, if these desires and longings are not fulfilled and completely contrary to the wishes of the child, make them feel frustrated and disappointed and anxious. As revenge of frustration and their disappointment, the child will seek peace, among others by consuming narcotics, and in meeting the financial needs to buy these drugs / illegal substances, in the end it will lead to the involvement of narcotics crimes as couriers.

Intercourse of children outside the home without the supervision of parents or from the family, the child is easily affected within the scope of children who are accustomed to doing things that are deviant, including in the involvement of narcotics crimes, in this case it begins with a narcotics dealer and will certainly lead to the drug user. Economic factors are also one of the crucial factors that greatly affect children. The dream of fulfilling the economic limitations of children, then the sale of narcotics which is very promising to generate large amounts of money will lead children to trafficking narcotics as an intermediary for the sale and purchase of narcotics, and a very good opportunity to become drugs users. Prevention. The efforts made in overcoming the criminal act of trafficking narcotics committed by children are divided into three, namely pre-emptive efforts, preventive efforts, and repressive efforts.

\section{References}

[1] Wahyu Rasyid, 2017., KAJIAN SOSIOLOGI HUKUM TERHADAP PENYALAHGUNAAN NARKOTIKA OLEH ANAK. Madani Regal Review. Vol 1. No. 2 Desember 2017. ISSN Cetak 2597-9353; Issn Online 2580-6319

[2] Soerjono Soekanto,2007., Factor-Faktor Yang Mempengaruhi Penegakan Hukum. Jakarta: Rajawali Press.

[3] Undang-Undang RI nomor 35 tahun 2014 Tentang Perubahan Atas Undang- Undang Nomor 23 Tahun 2002.

[4] Undang-Undang Nomor 23 Tahun 2002., Tentang Perlindungan Anak.

[5] John Locke, 2012., Pengertian Anak Sebagai Makhluk Sosial. http://duniapsikologi.com/ 4 Februari 2012.

[6] Kabar News, 2019. Kasus Narkoba di Makassar Meningkat Tahun 2019, Pelaku Didominasi Pengangguran. Breaking News Kota Makassar

[7] Parta Setiawan, 2020., Metode Penelitian Hukum - Pengertian, Macam, Normatif, Empiris, Pendekatan, Data, Analisa, Para Ahli. https://www.gurupendidikan.co.id/metode-penelitian-hukum/

[8] Polrestabes Makassar, 2019., 655 Orang Ditangkap di Makassar Karena Narkoba. kota Makassar.

[9] Undang-Undang Nomor 11 Tahun 2012., Tentang Sistem Peradilan Pidana Anak sebagaimana pengganti dari Undang-Undang Nomor 3 Tahun 1997 tentang Pengadilan Anak. 